\title{
Speciation environments and centres of species diversity in southern Africa: 2. Case studies
}

\author{
G. E. GIBBS RUSSELL* and E. R. ROBINSON**
}

\section{ABSTRACT}

Distributions of species in the grass genera Cymbopogon, Digitaria, Ehrharta and Stipagrostis are mapped to show that speciation within the phytochorion, where a genus has undergone major adaptive radiation ('phytochorial sympatry'), may be differentiated from speciation in a phytochorion outside this characteristic one ('phytochorial allopatry'). Testing of this hypothesis seems a fruitful field for systematists and will enhance our understanding of the flora.

\section{RESUME}

MILIEUX DE SPECIATION ET CENTRES DE DIVERSITE DES ESPËCES EN AFRIQUE DU SUD. 2. ETUDES PARTICULIEERES.

Les répartitions geographiques des espèces dans les quatre genres de graminées, Cymbopogon, Digitaria, Ehrharta et Stipagrostis, sont cartographiées pour montrer que la spéciation au sein de la phytochorie où un genre a connu une diversification évolutive importante ('sympatrie phytochoriale'), peut être différenciée de la spéciation au sein d'une phytochorie qui ne présente pas cette caractéristique ('allopatrie phytochoriale').

La vérification de cette hypothèse semble offrir un fructueux champ de recherches pour les systématiciens et améliorera notre connaissance de la flore.

\section{INTRODUCTION}

Speciation environments are areas where speciation (micro-evolution) is rapid or has been so in the recent past. It is important to define speciation environments not only for what this can tell us about the factors involved in micro-evolution of particular plant taxa, but also for what we can learn about the evolutionary process by examining the environments in which it is especially active. However, in attempting to define speciation environments for southern Africa, it has become obvious that a number of concepts and assumptions from taxonomy, phytogeography and chorology, biosystematics, ecology and evolutionary theory had to be examined in some detail. A review of the literature pertinent to these problems has been compiled by Robinson \& Gibbs Russell (in press). The aim of the present paper is to interpret the distributions of some southern African taxa in the light of current phytogeographical ideas and to examine these taxa in evolutionary terms. We believe that linking the mechanisms of evolution to phytogeography and chorology, as attempted here, will prove extremely fruitful for both fields.

Phytochoria, regions where large numbers of plant species ranges coincide and where there are numbers of endemics, have been put forward for Africa by several authors, especially White (1971, 1976) and Werger (1978), (Fig. 1.) In southern Africa there are six phytochoria, that fall into three major groups: 1, The Sudano-Zambezian Region

\footnotetext{
* Botanical Research Institute, Department of Agriculture, Private Bag X101, Pretoria 0001, South Africa.

** Department of Botany, University of the Witwatersrand, 1 Jan Smuts Avenue, Johannesburg 2001, South Africa.
}

and the Indian Ocean Coastal Belt Regional mosaics which both extend into southern Africa from the tropics; 2, Capensis and Karoo-Namib Region which are restricted to southern Africa; 3, Afromontane Region and Afroalpine Region that skip from the southern Cape to east Africa at high altitudes. Each of these groups exhibits one or more of the proposed conditions of a speciation environment discussed by Robinson \& Gibbs Russell (in press). Although a number of factors promoting speciation may be active in any phytochorion, each phytochorion is remarkable for at least one of the factors that have been suggested as major factors encouraging speciation, depending on its geographical position and overall climatic conditions.

The Sudano-Zambezian Region and the Indian Ocean Coastal Belt regional mosiac are continuations of tropical areas where, because of the high gamma diversity, speciation has been held to be most active. Stebbins (1974) has questioned this, suggesting that the gamma diversity is high because the extinction rate is low in a favourable tropical environment, not that the speciation rate is abnormally high. On the other hand, Simpson (1977) has pointed out that tropical environments would provide no less opportunity for speciation than other environments.

Capensis is well known for its fine-scale spatial heterogeneity. Topographic, edaphic or other environmental heterogeneity is thought to promote fragmentation of gene pools by providing isolated niches, which may be close together. The work of Lewis \& Raven (1958) on Clarkia in California and Gentry (1981) on Passiflora in South America indicates that edaphic factors alone may be enough to promote speciation.

The Karoo-Namib Region is an arid area with a fluctuating environment. According to the 'species 


\section{STUDIES}

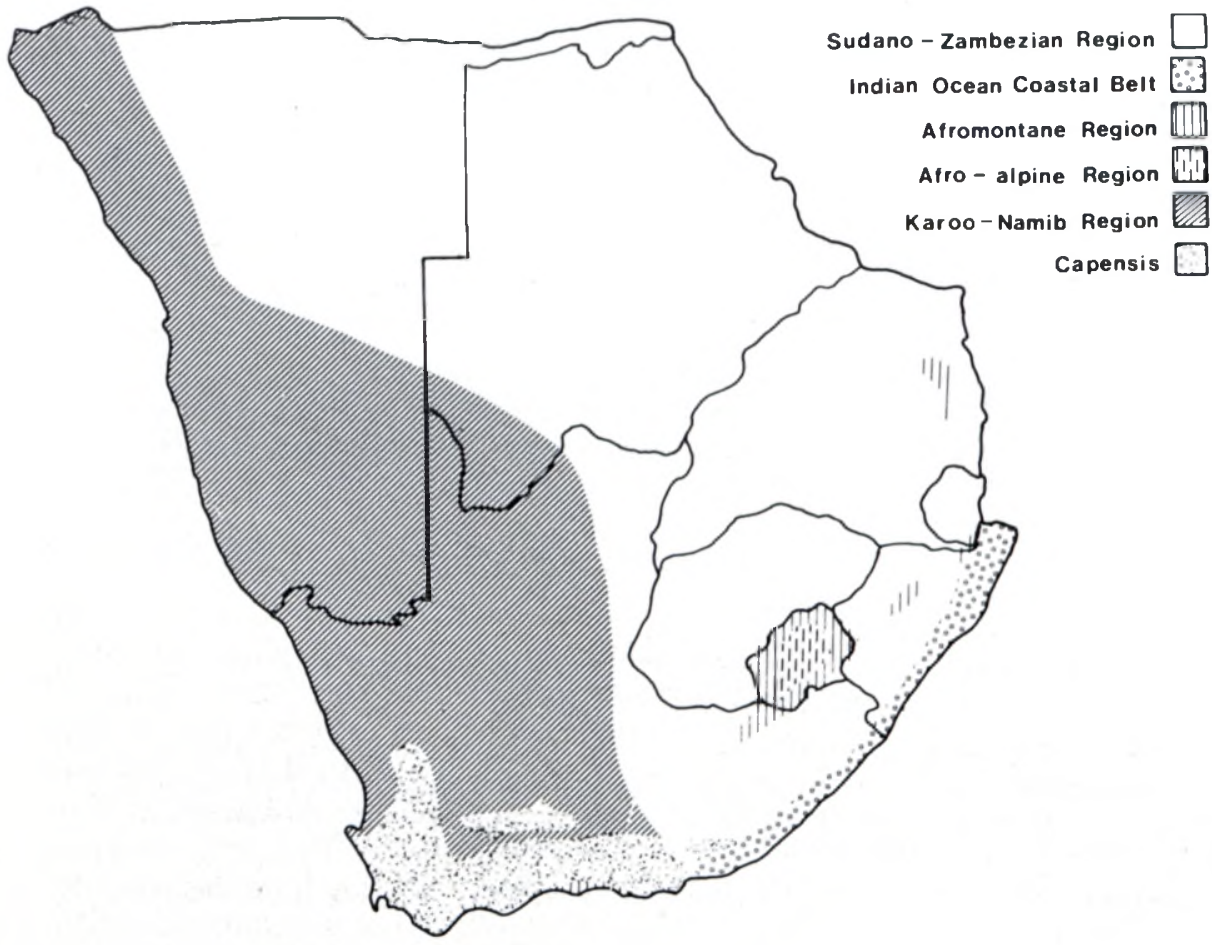

FIG. 1.-Phytochoria of southern Africa, according to Werger (1978).

pump' hypothesis of Valentine (1967), populations may become established during a time of unusually favourable conditions beyond the optimum range of the species. When conditions become severe, these populations will be isolated and therefore could differentiate from the main gene pool of the species. Stebbins $(1972,1974)$ also takes environmental instability as a key factor encouraging speciation. Arid regions are especially subject to climatic fluctuations, and arid regions for this reason have been strongly suggested by Stebbins (1952), Raven (1964) and Axelrod (1972) as areas that encourage speciation.

The Afromontane and Afroalpine Regions have both fine-scale environmental heterogeneity and local variations in climate brought about by changes in altitude and steep slopes.

In the following discussions, phytochoria are considered to be aggregates of taxa and not geographical areas (Clayton, 1980). We consider that the present phytochoria have existed in some form in the past long enough for the genera which characterize them to have undergone adaptive radiation. However, as climatic conditions have changed, the boundaries of the phytochoria may have shifted according to the tolerance limits of the plants which characterize them. Such a shift is taking place in the eastern Cape Province today as the Karoo-Namib species move eastwards into the Indian Ocean Coastal Belt (Gibbs Russell \&
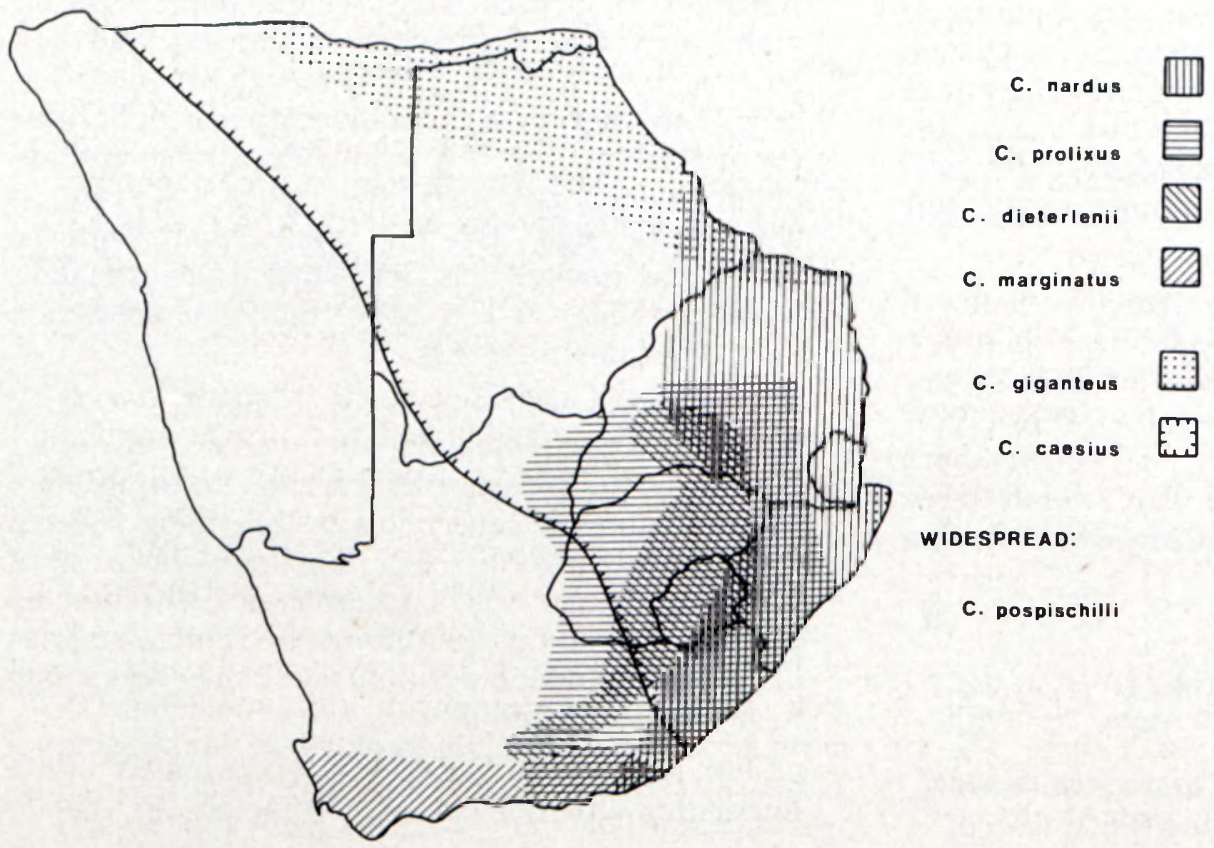

FIG. 2.-Distribution of species of Cymbopogon in southern Africa. 
Robinson, 1981). The geographical position of a phytochorion is therefore not to be regarded as static, but the environment within it, comprising a set of selection pressures, remains much the same.

The examples of grass genera discussed below show distribution patterns characteristic of the different phytochoria in southern Africa.

\section{DISTRIBUTION PATTERNS}

The genus Cymbopogon is a tropical genus that shows a decreasing number of species towards the south. Other groups with a similar pattern are Acacia, Andropogoneae, Ebenaceae and Combretaceae, all of which are taxa characteristic of the tropical phytochoria in southern Africa, with very few species extending into the winter rainfall region or the arid west. In Cymbopogon there are seven species in southern Africa (Fig. 2). Four of these, $C$. caesius, C. giganteus, C. pospischilii and C. nardus, extend into southern Africa from a wider distribution in tropical Africa, and the other three occur only in southern Africa, presumably having originated here. Each of the tropical species has a different distribution in southern Africa. $C$. cuesius and $C$. giganteus are closely related, and quite distinct from the other species. C. giganteus has the smallest intrusion into southern Africa, and is restricted to the tropical parts of the area. $C$. caesius extends further south and west, but is absent from the arid and winter rainfall regions. Neither of these species has given rise to any other extending further south or west than $C$. caesius. $C$. pospischilii is also quite distinct from the other species, and of all Cymbopogons has the widest distribution in southern Africa, extending into all parts, even the winter rainfall area of the south-western Cape and the arid Karoo and Namib desert.

C. nardus and its closely related species show a different situation. $C$. nardus itself is a tropical species that extends into southern Africa only in the northern and eastern Transvaal, to as far south as Natal, Lesotho and the eastern Cape. It is closely related to three species which are difficult to distinguish from it in some of the regions of sympatry, and which have a wider range in southern Africa than $C$. nardus. $C$. dieterlenii is restricted to high altitudes in the central Transvaal, the Orange Free State, Natal, Lesotho, and the eastern Cape, with a disjunct spread into the highlands of central South West Africa/Namibia. $C$. marginatus is restricted to the winter rainfall regions of the south-western Cape, and overlaps in distribution with $C$. nardus only in the eastern Cape, which has a variable rainfall regime. $C$. prolixus is imperfectly distinguished from $C$. nardus, differing from it mainly in its smaller size and longer ligule. Although $C$. prolixus does not venture into the winter rainfall regions, it does extend further into the semi-arid west than does $C$. nardus.

When confronted with the varying environments offered by southern Africa, each of the tropical species has behaved differently, and these differences illustrate several of the classic questions of speciation and endemism. Also, the behaviour of each of these species with respect to the phytochorial boundaries gives an indication of the different ways in which plants can respond to major habitat factors that characterize the phytochoria. The alternatives open to any species entering a new area are to spread unchanged ( $C$. pospischilii), not to spread at all ( $C$. giganteus, and to some extent $C$. caesius, which does not go beyond the borders of the tropical phytochoria) or to associate change and spread $(C$. nardus and its relatives, $C$. dieterlenii, $C$. marginatus and $C$. prolixus).

The derivitives of $C$. nardus have each originated by a different mode of speciation. $C$. marginatus is clearly allopatric, being totally outside the range of the parental species, and in a different phytochorion as well. $C$. dieterlenii may be an example of parapatric speciation, having arisen in a high altitude habitat surrounded by the range of the parental species. C. prolixus may be suggested as a case of stasipatric speciation, because its range overlaps the range of $C$. nardus, except that it extends farther into dry areas. However, until the cytogenetics of these species are worked out this remains speculation. Certainly $C$. prolixus seems more successful than its parent in medium-altitude dry rocky hillslopes, its preferred habitat. It is noteworthy that the only place where all four taxa exist together is the eastern Cape, which is also the only region where all the environmental factors that seem involved in the fragmentation of $C$. nardus occur.

But some basic questions remain unanswered. When spreading into southern Africa, why has $C$. nardus changed and $C$. pospischilii not changed, even though it is the most widespread of the seven species? Why have $C$. giganteus and $C$. caesius not spread beyond the boundaries of their ancestral phytochorion either changed or unchanged? The answer to these questions may lie in the concepts of canalization put forward by Stebbins (1974). Each of the responses to different phytochoria has occurred in a different group of related species in the genus. C. pospischilii, which alone has spread unchanged into all the phytochoria, has no near relatives in southern Africa. C. caesius and C. giganteus, which have not spread beyond their ancestral tropical phytochorion, are closely related to each other but to no other southern African species. $C$. nardus has not itself spread beyond the bounds of the ancestral phytochorion, but its closely related southern African endemic species all stretch into adjacent phytochoria. By Stebbins's proposal, each of the three groups of species has responded in a different way as a result of their inbuilt genetic constraints.

A genus with more species than Cymbopogon, also with its distribution centred in the tropical phytochoria is Digitaria, which in southern Africa has about 40 species and subspecific taxa (Kok, 1978). (Fig. 3). Three taxa are widespread, $D$. sanguinalis, which is weedy, $D$. argyrograpta and $D$. eriantha subsp. eriantha, which are common in a variety of habitats. Thirty of the species are restricted to the tropical phytochoria, some being of more widespread distribution within it than others. Three species, $D$. dinteri, $D$. polyphylla and $D$. seriata. occur only in the Karoo-Namib and the arid 


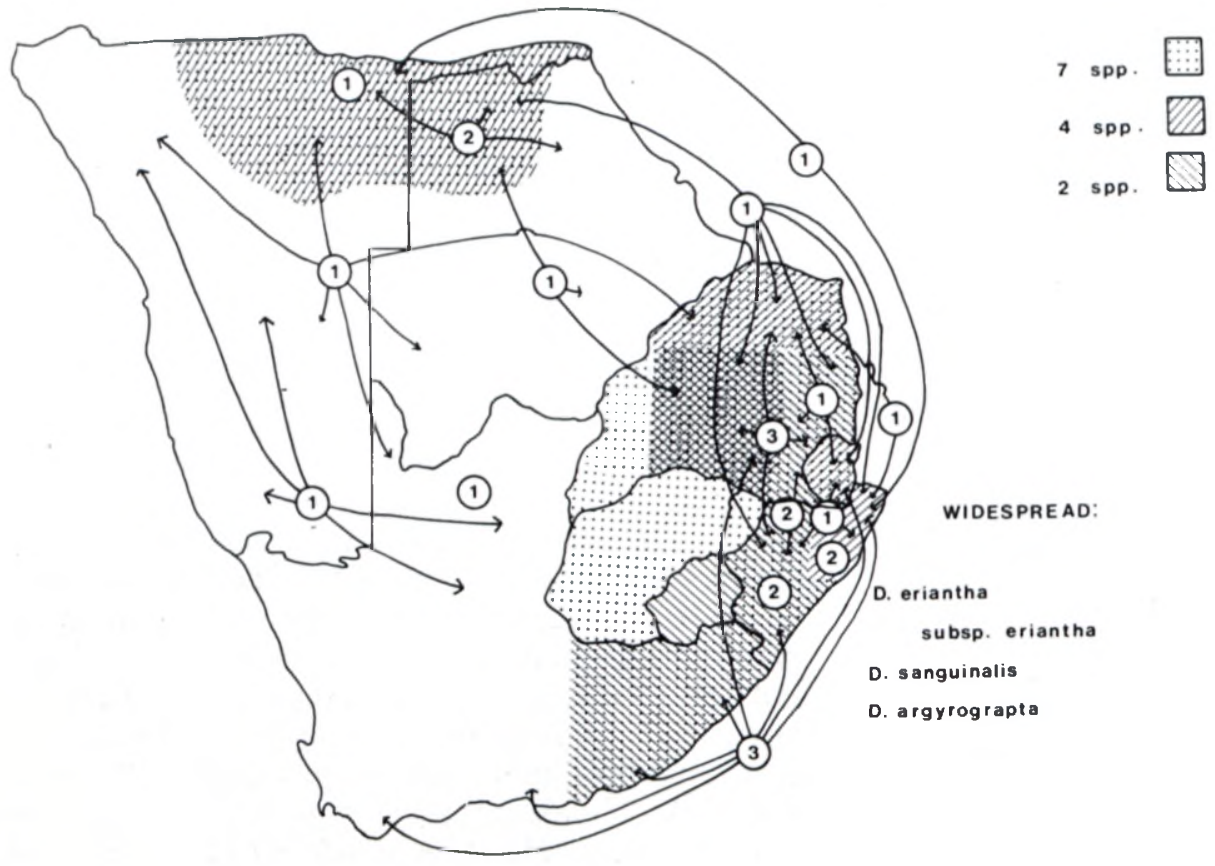

FIG. 3.-Distribution of species of Digitaria in southern Africa, based on Kok (1978).

western parts of the tropical phytochoria, and all are very closely related to the widespread $D$. eriantha subsp. eriantha. They have apparently been derived from it in a phytochorion outside the ancestral one for the genus. Three species, $D$. debilis, $D$. natalensis and $D$. scalarum, extend from the tropical phytochoria south-west to Capensis. In contrast to the arid-area species, which are all closely related to a single widespread taxon, each of these is a well-marked species with no very close relatives in southern Africa. Perhaps, as in Cymbopogon, it is an indication that canalization may affect the ability of a species to move out of the phytochorion characteristic of its genus.

Ehrharta is a south-western Cape winter rainfall (Capensis) genus of about 30 species and subspecific taxa (Fig. 4). Only two of the species are widespread, five are endemic to the arid northwestern Cape and South West Africa/Namibia (Karoo-Namib), one is endemic to the Drakensberg Mountains (Afromontane), and all the rest are restricted to the winter rainfall regions. The Drakensberg endemic, E. longigluma, is clearly very closely related to the widespread species, $E$. erecta. Of the five Karoo-Namib species, two, $E$. pusilla and $E$. virgata, are restricted to the southern Namib and Kalahari. Their nearest relative is the widespread E. calycina. Two others, E. barbinodis and $E$. brevifolia var. brevifolia, are centred on Namaqualand, and the nearest relative of each is a winter rainfall species whose range extends just to the southern edge of the dry areas ( $E$. villosa and $E$. brevifolia var. cuspidata respectively). E. melicoides, which occurs from the northern part of the south-western Cape to Namaqualand, is most closely related to $E$. erecta, which is widespread in the winter rainfall and tropical phytochoria, but does not extend into the arid regions.

Again we have a picture of a genus centred on one phytochorion, where it has many species, with a few species that have been able to spread into other phytochoria and have given rise to new species there. The proliferation of species in the southwestern Cape has been well documented in a number of genera (Weimarck, 1941; Goldblatt, 1978; Oliver, 1977), and is an example of parapatric speciation in an area remarkable for the variety of habitats available over short distances, in altitude, slope, available rainfall, edaphic factors, etc. The origin of endemic species at the ends of the ranges of the widespread species are examples of allopatric speciation taking place in arid (E. melicoides) or mountainous areas (E. longigluma).

Another grass genus, Stipagrostis, (De Winter, 1965) has its largest number of species in the arid areas of South West Africa/Namibia and the north-western Cape (Karoo-Namib). (Fig. 5.) One species is endemic to the winter rainfall region, (Capensis) and four species are found in the summer rainfall regions (Sudano Zambezian and Indian Ocean Coastal Belt), three of these being endemic to fairly small areas. S. zeyheri subsp. zeyheri, the south-western Cape taxon, is linked to the main distribution area of the genus through its nearest relative, $S$. zeyheri subsp. macropus, whose range is from the northern part of the south-western Cape to Namaqualand. The four taxa from the summer rainfall area fall into two groups. Two are subspecies in a complex that includes the two winter rainfall taxa mentioned above. S. zeyheri subsp. sericans is restricted to the highveld grasslands of the Sudano Zambezian phytochorion, and $S$. zeyheri subsp. barbata has a narrow range extending along the coast from the eastern Cape to Natal, in the Indian Ocean Coastal Belt. The other two, $S$. uniplumis var. neesii, widespread in the eastern half of the country, and $S$. proxima, found only in the north-eastern Cape, are closely related to taxa which are widespread in the western half of the country, $S$. uniplumis var. uniplumis and $S$. namaquensis 


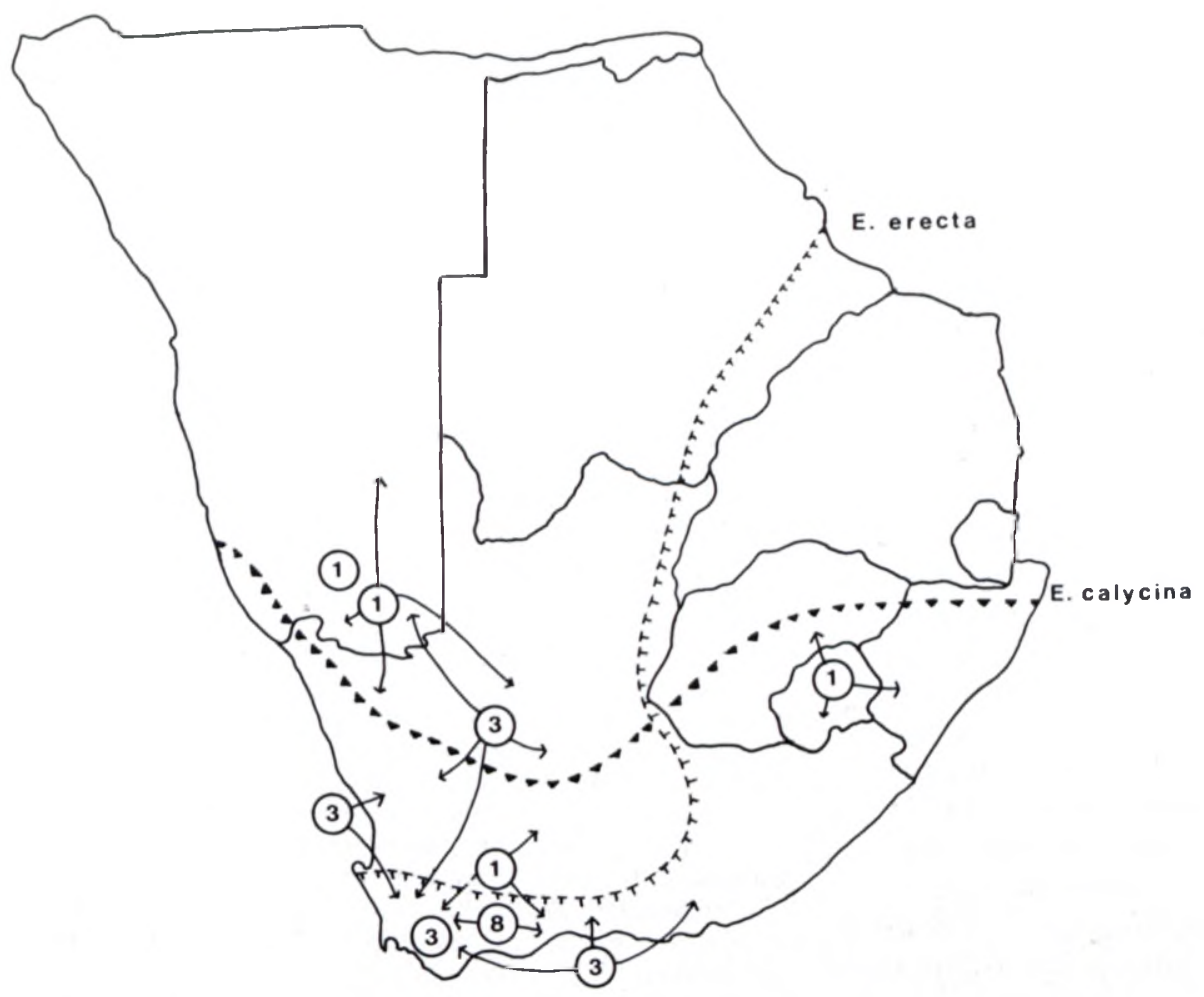

FIG. 4.-Distribution of species of Ehrharta in southern Africa.

respectively, and which link them to the main body of distribution of the genus in the Karoo-Namib.

Yet another pattern appears in which there is proliferation of species within a phytochorion, this time in the Karoo-Namib, accompanied by a few species that have spread outside the phytochorion and link endemic species in other phytochoria to the main area occupied by the genus.

\section{CONCLUSION}

All these examples show a similar process taking place. In each genus there is a majority of phytochorially sympatric species which have arisen as a result of adaptive radiation in the environment of the phytochorion characteristic of the genus. A few species are able to exist outside the characteristic phytochorion and are widespread. These may

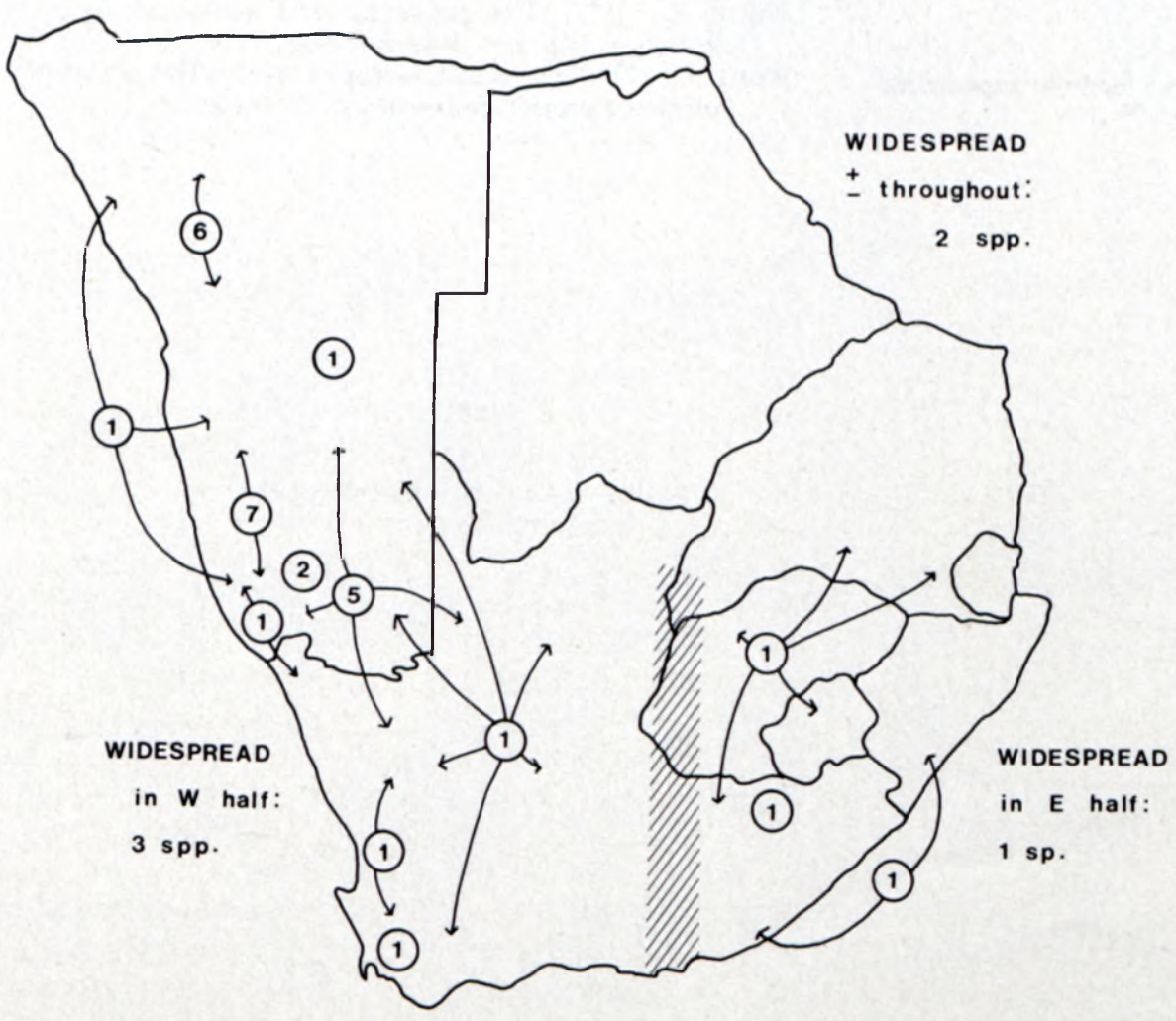

FIG. 5.-Distribution of species of Stipagrostis in southern Afri$\mathrm{ca}$, based on De Winter (1965). 


\section{STUDIES}

produce secondary species which are phytochorially allopatric to the main area of adaptive radiation of the genus. By the evidence of the examples discussed, these may often be narrow endemics. Finally, allogenous phyletic speciation may occur as some of these taxa extend back into the ancestral phytochorion and hybridize with taxa from which they may be imperfectly separated. It is here that one finds the problems of integradation so difficult to solve by classical taxonomic means.

Phytochorially sympatric speciation may be parapatric or stasipatric. Phytochorially allopatric speciation is allopatric with respect to the species of the original phytochorion, but within the second phytochorion speciation could also be stasipatric or parapatric. It can be followed by allogenic phyletic speciation if these species move back into the ancestral phytochorion. From this, it appears that there is no clear picture of a single speciation environment. Within each phytochorion there have been environments promoting adaptive radiation in genera that are then characteristic of that phytochorion. Outside the ancestral phytochorion there may be new environments promoting speciation in the few species that extend outside the original phytochorion.

It is clear that much basic work is required on aspects such as tests of hypotheses concerning modes of speciation, detailed studies of genetic heterogeneity and its relationship to temporal and spatial environmental heterogeneity, as well as biosystematic studies on major taxa, before fundamental progress can be made in relating chorology to evolution. We believe it is essential that biogeographers and ecologists take more notice of the implications of evolutionary theory for their disciplines.

\section{REFERENCES.}

AXELROD, D. I., 1972. Edaphic aridity as a factor in angiosperm evolution. Am. Nat. 106: 311-320.
Clayton, W. D., 1980. The chorology of Old World species of Gramineae. Kew Bull. 35: 135-171.

DE WINTER, B., 1965. The South African Stipeae and Aristideae (Gramineae). Bothalia 8: 199-404.

Gentry, A. H., 1981. Distributional patterns and additional species of the Passiflora vitifolia complex: amazonian species diversity due to edaphically differentiated communities. Plant Syst. Evol. 137: 95-105.

Gibbs Russell, G. E. \& Robinson, E. R., 1981. Phytogeography and speciation in the vegetation of the eastern Cape. Bothalia 14: 467-472.

GoldBLATT, P., 1978. An analysis of the flora of southern Africa: its characteristics, relationships and origins. Ann. Mo. bot. Gdn 65: 369-436.

KoK, P. D. F., 1978. 'n Hersiening van Digitaria Haller (Poaceae) in suidelike Afrika. D.Sc. (Plantkunde) tesis, Universiteit van Pretoria.

Lewis, H. \& Raven, P. H., 1958. Rapid evolution in Clarkia. Evolution 12: 319-336.

Oliver, E. G. H., 1977. An analysis of the Cape flora. In D. P. Annecke, Proceedings of Second National Weeds Conference of South Africa. Cape Town: Balkema.

Raven, P. H., 1964. Catastrophic selection and edaphic endemism. Evolution 18: 336-338.

Robinson, E. R. \& Gibbs Russell, G. E., 1982. Speciation environments and centres of species diversity in southern Africa: 1. conceptual framework. Bothalia 14. In press.

SIMPSON, B. B., 1977. Biosystematics and biogeography. In J.A. Romberger, Biosystematics in Agriculture, (Beltsville symposia in agricultural research; 2). Montclair: Allanhead \& Osmun.

Stebbins, G. L., 1952. Aridity as a stimulus to plant evolution. Am. Nat. 86: 33-44.

STEBBiNS, G. L., 1972. Ecological distribution of centres of major adaptive radiation in angiosperms. In $\mathrm{D}$. Valentine, Taxonomy, phytogeography and evolution. London: Academic Press.

Stebins, G. L., 1974. Flowering plants, evolution above the species level. London: Arnold.

ValenTINE, D., 1967. The influence of climatic fluctuations on species diversity within the Tethyan provincial system. In C. G. Adams \& D. V. Ager, Aspects of Tethyan biogeography, Systematics Assoc. Publ. No. 7: 153-166.

WeimarCK, H., 1941. Phytogeographical groups, centres and intervals within the Cape flora. Lunds Univ. Arssk. 2: 37: 5: $5-143$.

WERGER, M. J. A., 1978. Biogeography and ecology of southern Africa. The Hague: Junk.

WhITE, F., 1971. The taxonomic and ecological basis of chorology. Mitt. bot. StSamml. Münch. 10: 91-112.

WHITE, F., 1976. The vegetation map of Africa. This history of a completed project. Boissiera 24: 659-666. 